\title{
PARTICIPAÇÃO POLÍTICA DAS MULHERES: DESAFIOS PARA A EQUIDADE
}

\author{
Denise Almeida de Andrade \\ Pós-doutoranda em Direito pelo Programa Mestrado e \\ Doutorado em Direito Político e Econômico da \\ Universidade Presbiteriana Mackenzie (PNPD - CAPES). \\ Doutora e Mestre em Direito Constitucional pela \\ Universidade de Fortaleza (UNIFOR). \\ E-mail: andradedenise@ hotmail.com

\begin{abstract}
Mônica Sapucaia Machado
Doutoranda (CAPES-PROSUP) e Mestre pelo Programa de Mestrado e Doutorado em Direito Político e Econômico da Universidade Presbiteriana Mackenzie. Especialista em Administração Pública pela Fundação Getúlio Vargas. Advogada.

E-mail: monica.sapucaia@fgv.br
\end{abstract}

RESUMO: A participação política paritária das mulheres remanesce um desafio para a sociedade brasileira do século XXI. Em que pesem as iniciativas oficiais, com destaque para as cotas eleitorais regulamentadas pela Lei $\mathrm{n}^{\mathrm{o}} 12034 / 2009$, o percentual de cadeiras ocupadas no parlamento por mulheres no Brasil é, atualmente, de apenas 10,7\% para a Câmara Federal e 14,8\% para o Senado, enquanto as mulheres representam $51,5 \%$ da população total do país e $52 \%$ do total dos eleitores. Objetiva-se demonstrar que as cotas eleitorais não se traduziram em uma medida efetiva para superar essa disparidade, apesar, de contribuírem para alguns avanços. Utilizou-se de pesquisa bibliográfica e documental para o desenvolvimento deste texto. Indica-se, por fim, que do reduzido percentual de mulheres ocupantes de cargos públicos eletivos, a maior parte é oriunda de famílias com tradição masculina na política, pai, irmão, marido.

PALAVRAS-CHAVE: Participação política; Mulheres; Cotas eleitorais; Equidade.

\section{Women political participation: equity challenges}

ABSTRACT: The parity of women political participation remains a challenge for the Brazilian society of the 21st century. Regardless of the official initiatives, with emphasis on the electoral quotas regulated by Law 12034/2009, the percentage of seats occupied in parliament by women in Brazil is currently only 10.7\% for the Federal Chamber and $14.8 \%$ For the Senate, while women represent $51.5 \%$ of the country's total population and $52 \%$ of all voters. This article aims to demonstrate that the electoral quotas did not ensure the overcome this disparity, although, they contribute to some advances. Bibliographical and documentary research was used for the development of this text. Finally, it is pointed out that the small percentage of women in public elected positions is mostly from families with a male tradition in politics, father, brother, husband.

KEYWORDS: Political participation; Women; Electoral quotas; Equity. 


\section{INTRODUÇÃO}

A história das mulheres na vida política brasileira se mistura com a história do Brasil, apesar da ausência ou insuficiência de registros ${ }^{1}$. Objetiva-se resgatar parte desta história, partindo-se do final do século XIX, priorizando o movimento sufragista pela proximidade com o tema abordado neste artigo, qual seja, participação política das mulheres.

Para tanto, lançou-se mão, preferencialmente, da pesquisa bibliográfica e documental, conferindo-se atenção especial à legislação infraconstitucional sobre o tema, haja vista subsidiarem a maior parte das discussões sobre cotas eleitorais nos últimos anos no Brasil.

Na primeira parte do texto, aspectos e análises gerais sobre a política de cotas eleitorais, no Brasil, serão apresentados, com o intuito de esclarecer pontos controversos e justificar a relevância das cotas na busca por uma participação política significativa das mulheres.

Reflexões sobre as limitações e desafios das cotas eleitorais também serão implementadas. Ao final, duas pesquisas sobre o perfil das parlamentares brasileiras auxiliarão na compreensão do complexo cenário da política brasileira, a fim de que se possa avançar na proposta de equidade no parlamento.

\section{A BUSCA PELA IGUALDADE DE REPRESENTAÇÃO POLÍTICA DAS MULHERES BRASILEIRAS: O NECESSÁRIO RESGATE HISTÓRICO}

Inicia-se com o exemplo de Nísia Floresta, abolicionista, republicana, escritora nordestina, feminista, demonstra que a busca por direitos e oportunidades iguais têm um longo caminho. Ainda no século XIX, escreveu o livro Direitos das Mulheres e injustiças dos Homens (DUARTE, 2003, p.169) e defendeu abertamente o direito de as mulheres terem acesso à mesma educação que os homens, a fim de poderem "aproveitar todo o seu potencial humano, conquistarem autonomia econômica e política” (BANDEIRA; MELO, 2010, p. 11).

As mulheres se organizaram em associações em prol da libertação dos escravos. No Ceará, foi criada, em 1882, a Sociedade das Senhoras Libertadoras, o que impulsionou o debate no estado e ajudou na abolição da escravidão na província, em 1884, pela Assembleia Legislativa da Província do Ceará, quatro anos antes da Lei Áurea. (MARTINS, P., 2014).

Foi, também, a partir do fim século XIX que as mulheres brasileiras, influenciadas pelos movimentos sufragistas da Europa e dos EUA, intensificaram a luta por direitos políticos. Na Assembleia Constituinte de 1891, o pleito pela inserção do voto feminino esteve presente em inúmeros debates, o que justificou a expectativa de que a primeira Constituição Republicana do Brasil garantisse a sua participação. Não foi o que ocorreu. (SOIHET, 2000).

O artigo 70 da referida Constituição disciplinou: "São eleitores todos os cidadãos maiores de 21 anos que se alistarem na forma da lei" e, apesar da proibição não ter sido expressa, a jurisprudência da época entendeu que as mulheres não estavam contempladas entre os cidadãos. Como esclarece Pinto (2009, p. 46): "não se citou a mulher em 1891, não se lhes prescreveram limites, simplesmente se excluiu; não se reconheceu a sua existência".

\footnotetext{
1 Desde os tempos coloniais, mulheres participaram das lutas sociais, envolveram-se com as transformações políticas: "Desde a Colônia temos vozes femininas que preconizam a Abolição dos escravos, a instauração da República, a introdução do sufrágio universal” (GIULANI,2001, p. 644).
} 
O lugar social da mulher brasileira no final do século XIX era muito bem estruturado, ser mulher significava estar submetida ao poder masculino, a ser algo que pertencia ao homem, seja o pai, irmão ou o marido; e a República não traz inovações nesse quesito, como pondera Alvares: "A ausência de cláusulas a contemplar as mulheres na vertebração da legislação que faz avançar o regime democrático desse período configura o tratamento desigual de gênero, fortalecendo as estruturas patriarcais do comportamento político do demos". (ÁLVARES, 2014, p. 135).

As mulheres, entretanto, não desistiram e fundaram, em dezembro de 1910, no Rio de Janeiro, o Partido Republicano Feminino. O partido conseguiu o registro oficial em 1911 e se tornou um espaço de luta pelo direito ao voto: "a criação do partido foi marcante, uma vez que se constituiu em um partido político formado por pessoas sem direitos políticos e cuja possibilidade de atuação teria que se dar, portanto, fora da ordem estabelecida" (PINHEIRO, 2006, p. $62)$.

Nesse momento, a luta das mulheres era pela igualdade do direito ao voto, chamado por Ana Costa (2005) de O feminismo bem-comportado, que buscava o reconhecimento de cidadania, não albergando as discussões acerca da necessária superação dos estereótipos de gênero. A proposta não era de romper com o papel social da mulher, de mãe, dona de casa e esposa, mas sim garantir às mulheres direitos políticos, com o objetivo, inclusive, de representar questões femininas, voltadas ao bem da família, ao resguardo da sociedade.

\begin{abstract}
Esse primeiro momento do movimento feminista, em linhas gerais, pode ser caracterizado como de cunho conservador no que se refere ao questionamento da divisão sexual dos papeis de gênero, inclusive reforçavam esses papéis, estereótipos e tradições na medida em que utilizavam as ideias e representações das virtudes domésticas e maternas como justificativas para as suas demandas (COSTA, A., 2005, p.3).
\end{abstract}

As sufragistas brasileiras não estavam buscando mudar a relação de gênero, o domínio patriarcal da sociedade burguesa. A luta era por um status de cidadã, por meio da igualdade formal, do direito ao voto. Neste sentido, tem-se a definição do Partido Liberal Feminino, fundado por Julita Monteiro Soares, nos anos de 1920, que defendia os direitos políticos das mulheres porque tinham "qualidades femininas", como "horror à violência, inquebrantável fidelidade às leis de Deus", que lhes garantiriam capacidade de "salvar" a sociedade: Essas declarações mostravam uma visão naturalizada da mulher na medida em que não se pretendia mudar a estrutura familiar e os papéis de esposa e mãe, ao contrário, seriam os "dotes naturais" propulsores dos avanços dos direitos políticos das mulheres. (BANDEIRA; MELO, 2010, p. 14).

Destaca-se, neste cenário, a liderança feminista da bióloga Bertha Lutz (MARQUES, 2000, p. 106). Filha de estrangeiros e formada pela Universidade de Sorbonne, em Paris, se deparou com um país em que as mulheres ainda eram consideradas "cidadãs de segunda classe". Em 14 de dezembro de 1918, Bertha Lutz escreveu o artigo Somos filhos de Tais Mulheres, no qual defendeu o voto feminino:

\footnotetext{
As mulheres russas, finlandesas, dinamarquesas, norueguesas, suecas, alemãs e inglesas - quer dizer, uns cento e vinte milhões de mulheres na velha Europa — já partilham ou brevemente partilharão do governo, não só contribuindo com seu voto para a eleição dos legisladores, como podendo ser elas próprias para o exercício do poder legislativo. (MARQUES, 2000).
}

Em 1922, no mesmo ano da fundação do Partido Comunista do Brasil, Bertha Lutz criou a Federação Brasileira pelo Progresso Feminino, por meio da qual iniciou um processo de negociação pelo voto feminino junto à classe elite política do país. Lutz pertencia à elite intelectual e econômica e organizou o movimento sufragista a partir de uma postura de diálogo com os homens (SOIHET, 2006). 
A estratégia do movimento era o do convencimento da importância do voto para as mulheres e não do enfrentamento sobre a condição da mulher na sociedade (MARQUES, 2004), o que se traduziu em apoio de mulheres de famílias tradicionais, o que não aconteceu em outras iniciativas da época.

[...] cercada que foi por colaboradoras egressas de famílias de grande prestígio social, como Maria Eugenia Celso, Jeronima Mesquita e Margarida Lopes de Almeida, conquistou, palmo a palmo, as metas definidas pela agenda de sua organização, sem suscitar reações contrárias que denegrissem a sua conduta pessoal, nem a de suas colaboradoras. (MARQUES, 2004, on line).

Berta Lutz recorria à lógica já exposta anteriormente: a de concentrar os esforços, em princípio, na pauta dos direitos políticos, e em um segundo momento as demandas trabalhistas. Sua luta não tentava fazer com que a mulher confrontasse o seu lugar social, mas sim lutasse por ampliá-lo.

Celina Guimarães Vieira, professora natural de Mossoró - RN, tornou-se a primeira eleitora brasileira, com base na alteração da constituição estadual do Rio Grande do Norte, que determinou, no artigo 77: "No Rio Grande do Norte poderão votar e ser votados, sem distinção de sexos, todos os cidadãos que reunirem as condições exigidas por lei” (ALVES, B., 1980, p. 117).

Ainda no Rio Grande do Norte, Alzira Soriano foi eleita, em 1928, a primeira prefeita do Brasil, pela cidade de Lajes "pelo Partido Republicano, e venceu com 60\% dos votos" (TSE, on line). Porém, por decisão da Comissão de Poderes do Senado, não conseguiu concluir seu mandato (TSE, on line).

Em 1932, o então presidente Getúlio Vargas promulgou o Decreto ${ }^{\circ}{ }^{21.076 / 32}$, instituindo o Código Eleitoral Brasileiro e determinando, em seu artigo $2^{\circ}$, que eram eleitores todos aqueles cidadãos maiores de 21 anos, sem discriminação por sexo. Como aponta Rita Araújo (2003, p. 135): “As mulheres brasileiras adquiriam assim, pela primeira vez, e após árdua luta, cidadania política, contribuindo para o aumento significativo do número de votantes no país"2.

No Brasil, em um primeiro momento, só puderam votar as mulheres casadas, desde que autorizadas pelos maridos, as viúvas e as solteiras com renda. $\mathrm{Na}$ Assembleia Constituinte de 1934, referidas restrições foram extintas e o voto feminino se consolidou como um direito de todas as mulheres. As imposições que se mantiveram eram as mesmas para ambos os sexos, só podiam votar os alfabetizados, e estavam excluídos os mendigos, os clérigos regulares e os praças de pré ${ }^{3}$.

Em 1932, a médica paulista Carlota Pereira de Queiroz foi eleita, pelo estado de São Paulo, a primeira deputada federal do Brasil. Nas eleições regionais de 1934 foram eleitas deputadas em Santa Catarina, em Alagoas, no Rio Grande do Norte e em São Paulo (BANDEIRA; MELO, 2010).

Bertha Lutz foi candidata pelo Partido Autonomista do Distrito Federal, mas não se elegeu, ficando apenas com a primeira suplência, o que fez com que ocupasse a cadeira na câmara federal após a morte de Candido Pessoa, em 1936.

\footnotetext{
2 No contexto da América Latina, o Brasil foi o terceiro país a garantir o direito de voto às mulheres, antecedido apenas pelo Equador e Chile. Portugal, país colonizador do Brasil, só retirou todos os empecilhos ao voto das mulheres em 1976. Seguindo na verificação do contexto internacional, Nova Zelândia, Inglaterra e EUA são vanguardistas neste aspecto. Por outro lado, a França, Estado reconhecido pelo engajamento político da população, só autorizou o voto feminino em 1945.

3 Um praça de pré (referido ocasionalmente pelo termo arcaico: praça de pret) ou simplesmente praça é um soldado que pertence à categoria inferior da hierarquia militar.
} 
No ano seguinte, Getúlio Vargas instaurou o regime ditatorial no país e o recém conquistado direito das mulheres ao voto foi suspenso. Durante quase 10 anos, nem homens nem mulheres exerceram seus direitos políticos e democráticos.

Após a segunda guerra mundial, aflorou o desejo por democracia e liberdade. No Brasil, convocou-se uma nova Assembleia Constituinte, em 1946, e apesar de dezoito mulheres terem se candidatado a deputadas federais, nenhuma foi eleita para compor a Assembleia. Nas eleições de 1950, Ivete Vargas, sobrinha-neta de Getúlio Vargas, elegeu-se por São Paulo e tornou-se a única mulher da nova legislatura.

Nas eleições de 1954, Ivete Vargas foi reeleita e Nita Costa foi eleita pela Bahia, mas nas duas legislaturas seguintes, 1958 e 1962, apenas Ivete Vargas se manteve na Câmara Federal.

\begin{abstract}
Nos anos compreendidos entre 1932 e 1964 as mulheres participaram da vida política nacional de forma enviesada. No espaço público teve-se duas deputadas federais, algumas deputadas estaduais e poucas prefeitas. Nas eleições gerais de 1945 nenhuma mulher foi eleita para a Assembleia Constituinte de 1946 e, ironicamente, a redemocratização, a efervescência pela derrota do nazi-fascismo, não ampliou a participação feminina no cenário político partidário (BANDEIRA; MELO, 2010, p. 21-22).
\end{abstract}

Após o golpe de 1964, as esposas, irmãs e mães dos deputados cassados pelos militares se candidataram a fim de representá-los, o que contribuiu para que seis mulheres fossem eleitas em 1965. Todavia, nas eleições de 1974, apenas uma mulher foi eleita para a Câmara Federal, em mais uma expressão dos retrocessos trazidos pela ditadura militar.

A primeira mulher a ocupar uma cadeira no Senado Federal foi Eunice Michilles, em 1979, na vaga de João Bosco Lima, que faleceu durante o mandato. Apenas em 1990 duas senadoras são, efetivamente, eleitas para o cargo.

A Organização das Nações Unidas - ONU aprovou, em 1979, a Convenção para a eliminação de todas as formas de discriminação contra a mulher. Cinco anos depois, o Brasil ratificou, com ressalvas, a convenção as quais foram retiradas em 1994. Neste momento, o Brasil assumiu um compromisso internacional de buscar a igualdade de gênero, por meio de ações concretas:

\begin{abstract}
Art. 7 - Os Estados-Partes tomarão todas as medidas apropriadas para eliminar a discriminação contra a mulher na vida política e pública do país e, em particular, garantirão, em igualdade de condições com os homens, o direito a:

b) participar na formulação de políticas governamentais e na execução destas, e ocupar cargos públicos e exercer todas as funções públicas em todos os planos governamentais.
\end{abstract}

Nas eleições de 1982, em meio ao processo de redemocratização do país, incrementou-se a participação política das mulheres; foram eleitas oito deputadas federais e na Assembleia Constituinte de 1987 contou-se com vinte e quatro mulheres deputadas constituintes.

Em 1995, teve lugar em Beijing, a IV Conferência Mundial sobre a Mulher, que culminou em uma plataforma de ação para os países signatários, entre eles o Brasil, destinada ao empoderamento da mulher ${ }^{4}$.

A Declaração e a Plataforma de Beijing abordam diversos temas afeitos aos direitos das mulheres, dentre os quais destaca-se, para a presente análise, as contribuições sobre a necessária participação ativa da mulher em todas as dimensões da vida pública e privada. A Convenção e a Plataforma (ONU Mulheres, 1995, on line) abriram caminho para a idealização de uma política

4 Empoderamento é "um construto que liga forças e competências individuais, sistemas naturais de ajuda e comportamentos proativos com políticas e mudanças sociais". PERKINS, Douglas D.; ZIMMERMAN, Marc A. Empowerment theory, research, and application. American journal of community psychology, n. 5, v. 23, 1995, p.1 (tradução livre). 
pública que estimule a participação feminina nos espaços da política institucional, salientandose que na última década do século XX a representatividade das mulheres não chegava a $6 \%$ do total de cadeiras do Congresso Nacional brasileiro. ${ }^{5}$

A conclusão da Convenção de Beijing é que o caminho para se conseguir paridade nos espaços sociais, políticos e econômicos passa por garantir que poder e responsabilidades (do lar, do trabalho, da sociedade) sejam compartilhados. É "mediante uma participação plena e em igualdade de condições no processo de tomada de decisões econômicas, sociais, culturais e políticas" (ONU Mulheres, 1995, on line) que se chegará a uma igualdade material entre homens e mulheres. Nas palavras de Sacchet (2009, p. 308): "Desde a IV Conferência da Mulher em Beijing, em 1995, fóruns das Nações Unidas têm afirmado a importância da paridade de homens e mulheres em espaços parlamentares e em organizações políticas".

A baixa participação das mulheres nos espaços políticos não é uma prerrogativa da política brasileira. Poucos países ocidentais conseguem ter uma participação expressiva das mulheres no parlamento (IPU, 2017) ${ }^{6}$.

\section{INSTRUMENTOS NORMATIVOS DA POLÍTICA DE COTAS ELEITORAIS BRASILEIRAS}

A primeira política de cotas eleitorais estabelecida no Brasil, pela Lei $n^{\circ}$ 9.100/19957, referiu-se especificamente às eleições municipais, a serem realizadas em outubro de 1996.

$\mathrm{O}$ artigo $11^{\circ}, \S 3^{\circ}$, versando sobre o registro dos candidatos, determinou que os partidos políticos deveriam preencher as vagas nas chapas ou coligações eleitorais com, no mínimo, $20 \%$ de mulheres. Firmou-se a obrigatoriedade do preenchimento de vagas na chapa eleitoral por mulheres (em um percentual mínimo de $20 \%$ ), contudo, não se tratou sobre recurso para campanha, tempo de propaganda na televisão ou medidas (ainda que de curto prazo) para garantir igualdade de oportunidade na disputa; definiu-se, exclusivamente, o espaço na lista e um percentual mínimo.

O caput do artigo 11 determinou que os partidos políticos poderiam registrar chapas com até $120 \%$ do número de lugares a preencher, isto é, os partidos não diminuiriam em $20 \%$ a participação dos candidatos homens para acomodar as candidatas, os partidos poderiam aumentar o número de candidatos para incluir o percentual mínimo de mulheres.

Apesar de pouco complexa, referida alteração suscitou uma série de discussões acerca de sua constitucionalidade: "deu margem ao questionamento sobre a inconstitucionalidade do artigo, pois estabeleceu um tratamento diferenciado para o sexo feminino" (ALVES, J., 2009, p. 19).

5 Em 1998, foram eleitas 29 deputas, um total de 5,6\% do total de cadeiras da Câmara dos Deputados. Dados do Tribunal Superior Eleitoral (TSE, on line).

6 Vale ressaltar que Ruanda e Bolívia são os únicos países, entre os 190 analisados pela União Interparlamentar (InterParlamentary Union) onde as mulheres são a maioria no parlamento 61,3\%, e 53,1\% respectivamente. Em todos os outros, a proporção de homens é maior do que o de mulheres, inclusive em países com maior equidade de gênero, como a Finlândia, onde elas são 42\%, a Dinamarca, 37, 4\%, Austrália, 28, 7\%. (IPU,2017). O Canadá, onde o primeiro ministro, em 2016, se declarou feminista ${ }^{6}$ apenas $26,3 \%$ do parlamento é composto de mulheres.

7 Destaca-se a liderança da deputada Marta Suplicy, com o apoio da bancada feminina, para garantir a aprovação da referida lei. 
Passados dois anos, foi sancionada a Lei ${ }^{\circ}$ 9.504/1997, nova lei eleitoral brasileira, que definiu como política de cotas, a reserva de vagas. Os partidos não estavam obrigados a preencher as vagas com mulheres, mas sim reservá-las; logo, caso não conseguissem ou não desejassem, poderiam apenas não preenchê-las.

A Lei ${ }^{\circ} 9.504 / 1997$, ao prever a política de cotas, no artigo $10, \S 3^{\circ}$, optou pelo uso do termo sexo e não mulher: "cada partido ou coligação deverá reservar o mínimo de trinta por cento e o máximo de setenta por cento para candidaturas de cada sexo".

A mencionada lei previu, ainda, o aumento do percentual mínimo de vagas de candidaturas por sexo, que passou de $20 \%$ para $30 \%$, e a ampliação da regra para todos os níveis (municipal, estadual e federal, tendo em vista que a Lei $n^{\circ}$ 9.100/1995, regulamentava apenas a eleição municipal de 1996).

A Lei ${ }^{\circ}$ 9.504/1997 aumentou o número de candidatos que cada partido poderia inscrever em suas chapas, de forma permanente e para todas as eleições, o que conferiu aos partidos políticos uma espécie de bônus: "Art. $10^{\circ}$ - Cada partido poderá registrar candidatos para a Câmara dos Deputados, Câmara Legislativa, Assembleias Legislativas e Câmaras Municipais, até cento e cinquenta por cento do número de lugares a preencher" (grifou-se).

Os partidos políticos, que até então tinham que formar as suas chapas com o número de cadeiras existentes na casa legislativa, passaram a poder contar com 50\% a mais de candidatos do que de cadeiras, ou seja, com uma lista com nomes que corresponderiam a $150 \%$ do número de assentos disponíveis.

O número de candidatos aptos a disputar uma vaga se ampliou (de $100 \%$ para $150 \%$ das cadeiras em disputa) e a não obrigatoriedade de preenchimento das cotas foi mantida, a exemplo da legislação de 1995, o que resultou em diminuição do impacto da medida aprovada, e retirou o seu caráter 'polêmico' e o interesse pelo debate (PINHEIRO, 2006, p. 71).

Apesar das inovações, o impacto causado pelas duas leis foi pequeno nas eleições municipais para a legislatura 1997-2000: as mulheres passaram de $8 \%$ para apenas $11 \%$ das cadeiras legislativas municipais. (TSE, online)

O cenário das eleições para o Congresso Nacional foi ainda pior. Apesar da cota, apenas 29 mulheres foram eleitas deputadas federais, quatro a menos do que na legislatura anterior. A despeito da legislação, o Brasil chegou ao século XXI com uma representação feminina no Congresso Nacional por volta de $6 \%$.

A avaliação feita na época responsabilizou o pouco tempo de existência da lei e a má divulgação junto à sociedade pelo fraco desempenho da ação afirmativa (MIGUEL, 2000, p. 100).

Em 2002, foram eleitas 42 mulheres para a câmara federal dos deputados, o que representou um aumento de $45 \%$ em relação à eleição anterior. O resultado foi expressivo e transformou a bancada de mulheres deputadas em um grupo numericamente importante.

É inequívoco que garantir um número significativo de mulheres no Congresso Nacional não assegura uma uniformidade de discurso ou um alinhamento de pauta política em prol da equidade de gênero. Reconhece-se as singularidades e multiplicidades de anseios e identidades femininas e, desta forma, não se poderia almejar uma linearidade de atuação política.

Todavia, deve-se reconhecer que há demandas que afetam diretamente as mulheres, como a violência doméstica e familiar (em que pese espraiar suas consequências por toda a sociedade), e que são temas negligenciados pela sempre volumosa agenda política nacional. 
Diante disto, pugnar por uma representação proporcional de mulheres e homens nos espaços públicos de poder, significa maximizar as chances de se abordar temas historicamente alijados das discussões políticas.

É neste sentido que se entende que a aprovação da Lei $\mathrm{n}^{\circ} 11.340 / 2006^{8}$ (Lei Maria da Penha) não foi um acaso. Apesar do projeto de lei ter sido encaminhado pelo Poder Executivo, em resposta à condenação brasileira pelo Sistema Interamericano de Proteção Internacional dos Direitos Humanos, a bancada feminina, em conjunto com a então Secretaria de Política para as Mulheres da Presidência da República-SPM, trabalharam arduamente para agilizar a tramitação do projeto de lei nas casas legislativas e contribuíram para sua rápida aprovação (CALAZANS, CORTES, 2011). Referida Lei, após dez anos de sua publicação, ainda é o instrumento jurídico nacional mais importante no enfrentamento à violência doméstica e familiar contra a mulher.

Na eleição seguinte, em 2006, o número de deputadas passou de 42 para 45, um acréscimo modesto, que representou a estagnação da participação feminina em menos de $10 \%$ do total de congressistas na casa legislativa federal.

Percebe-se, pois, que instituir uma política de cotas não é suficiente para alterar uma conformação histórico política de décadas. Ações isoladas e sem continuidade há muito são descritas como ineficientes para modificar qualquer aspecto da realidade, especialmente, quando se refere à política, setor historicamente dominado por homens. As contribuições de Eneida Martins (2007, on line) corroboram esse pensamento: "No Brasil, as cotas não promoveram mudanças significativas no quadro da Câmara dos Deputados, por que não ampliaram os caminhos para a vitória eleitoral das mulheres. As candidatas ainda precisam, em um primeiro momento, do eleitor".

Nesse mesmo sentido, as palavras de Miguel (2003, p. 31) sobre a participação política das mulheres após a inclusão das cotas:

\begin{abstract}
Nosso sistema eleitoral, com listas abertas, apresenta vantagens do ponto de vista da autonomia dos eleitores, mas é negativo para política de cotas. Pior ainda é o fato de que a legislação não exige o preenchimento das vagas reservadas às mulheres, não lhes garante recursos nem tempo de rádio e TV e permite que cada partido lance um número de candidatos superior às vagas em disputa. Diante de tudo isso, não é de espantar que as cotas eleitorais tenham tido um reflexo modesto na composição do poder legislativo.
\end{abstract}

Ainda sobre o tema, Clara Araújo (2001, on line) arremata:

\begin{abstract}
$\mathrm{Na}$ ausência de mecanismos objetivos que gerem ou estimulem debates, o processo vem sendo marcado por procedimentos burocráticos e formais, Com efeito, a característica do sistema eleitoral brasileiro, aliada ao tipo de legislação adotada, ajudanos a entender o porquê de as duas leis de cotas no Brasil terem sido apoiadas com relativa facilidade por todos os partidos, independentes dos perfis ideológicos: em virtude do seu baixo impacto quanto à capacidade de alterar padrões de competição eleitoral no país e, consequentemente, modificar a situação das mulheres na representação proporcional.
\end{abstract}

\footnotetext{
8 A Lei 11.340/2006 cria mecanismos para coibir a violência doméstica e familiar contra a mulher, nos termos do $\S 80$, do art. 226, da Constituição Federal, da Convenção sobre a Eliminação de Todas as Formas de Discriminação contra as Mulheres e da Convenção Interamericana para Prevenir, Punir e Erradicar a Violência contra a Mulher; dispõe sobre a criação dos Juizados de Violência Doméstica e Familiar contra a Mulher; altera o Código de Processo Penal, o Código Penal e a Lei de Execução Penal; e dá outras providências. Disponível em: http://www.planalto.gov.br/ ccivil_03/_ato2004-2006/2006/lei/111340.htm. Acesso em: 30 abr. 2016.
} 
Em 2009, foi aprovada a Lei $\mathrm{n}^{\circ} 12.034^{9}$, conhecida como a minirreforma eleitoral, que alterou a lei dos partidos políticos, a já comentada Lei $n^{\circ}$ 9.504/1997. A minirreforma trouxe três conquistas para as mulheres: a participação de $5 \%$ no fundo partidário para a criação e a manutenção de programas de promoção e difusão da participação política das mulheres ${ }^{10} ; 10 \%$ do tempo de propaganda partidária para promover e difundir a participação política feminina ${ }^{11}$; e a obrigatoriedade do preenchimento do mínimo de $30 \%$ e máximo de $70 \%$ para a candidatura de cada sexo (em substituição à anterior "reserva de vagas"). A partir de 2009, não seria mais possível apenas reservar, nem deixar as vagas vazias; o preenchimento do percentual mínimo por cada um dos sexos passou a ser obrigatório.

Tais modificações legais, apesar de não comporem, especificamente, a regra de cotas eleitorais, inserem-se no conjunto de medidas legais que visam a uma maior igualdade de gênero nas esferas de poder no Brasil.

A obrigação de respeitar a proporção mínima de $70 \%$ e $30 \%$ para cada um dos sexos, viabilizou que os partidos apresentassem, mais uma vez, um número de candidatos maior do que o número de vagas. Essa medida que ficou conhecida como cláusula de escape que significa a possibilidade de as chapas serem formadas por até $150 \%$ de candidatos do número de cadeiras a preencher. Na prática, a cláusula de escape se traduziu no aumento das vagas para os homens, como explicita Thiago Costa (2008, p. 33):

\footnotetext{
Na prática, o que aconteceu foi um aumento de vagas para os homens. Numa localidade cujo parlamento possuísse 100 assentos, por exemplo, um partido qualquer podia anteriormente lançar 100 candidaturas. Se as cotas fossem aplicadas sem aumentar o número de candidaturas, o partido teria que lançar no máximo 70 homens e no mínimo 30 mulheres na disputa eleitoral. Com a ampliação do número de candidaturas possíveis para $150 \%$ dos assentos nos parlamentos, na mesma localidade um partido passou a poder lançar 150 candidatos. Destes 105 podem ser homens $(\mathbf{7 0} \%)$ e 45 mulheres (30\%). (grifou-se).
}

Uma outra dificuldade para tornar efetiva a cota eleitoral foi a ausência de sanção para os partidos que não respeitassem os limites estabelecidos na lei. Não havia nenhuma espécie de ônus pelo descumprimento da proporção $70 \%-30 \%$, não havia, pois, obrigatoriedade real: "Nenhuma das duas leis previu punições aos partidos que não cumprissem ou preenchessem as cotas, o que constrangeu a capacidade das cotas em promover mudanças na composição por sexo das listas de candidatos" (COSTA, T., 2008, p. 32).

9 As conquistas da lei são resultado de reivindicações antigas dos defensores das cotas eleitorais de gênero, tendo, inclusive, composto o relatório final da comissão tripartite (representantes dos poderes legislativo, executivo e de organizações da sociedade civil).

${ }^{10}$ Artigo 44: "Criação e manutenção de programas de promoção e difusão da participação política das mulheres conforme percentual que será fixado pelo órgão nacional de direção partidária, observando o mínimo de $5 \%$ (cinco por cento) do total". Este inciso teve sua redação alterada em 2015, pela Lei no 13.165, veja-se a redação atual: Artigo 44: "Os recursos oriundos do Fundo Partidário serão aplicados: [...] V - na criação e manutenção de programas de promoção e difusão da participação política das mulheres, criados e mantidos pela secretaria da mulher do respectivo partido político ou, inexistindo a secretaria, pelo instituto ou fundação de pesquisa e de doutrinação e educação política de que trata o inciso IV, conforme percentual que será fixado pelo órgão nacional de direção partidária, observado o mínimo de 5\% (cinco por cento) do total" (BRASIL, 1995, on line).

11 Artigo 45: "A propaganda partidária gratuita, gravada ou ao vivo, efetuada mediante transmissão por rádio e televisão será realizada entre as dezenove horas e trinta minutos e as vinte e duas horas para, com exclusividade: [...] IV Promover e difundir a participação política feminina, dedicando às mulheres o tempo que será fixado pelo órgão nacional de direção partidária, observado o mínimo de $10 \%$ (dez por cento)". Este inciso teve sua redação alterada em 2015 , pela Lei $n^{\circ} 13.165$, veja-se a redação atual: Artigo 45: "A propaganda partidária gratuita, gravada ou ao vivo, efetuada mediante transmissão por rádio e televisão será realizada entre as dezenove horas e trinta minutos e as vinte e duas horas para, com exclusividade: [...] IV promover e difundir a participação política feminina, dedicando às mulheres o tempo que será fixado pelo órgão nacional de direção partidária, observado o mínimo de $10 \%$ (dez por cento) do programa e das inserções a que se refere o art. 49” (BRASIL, 1995, on line). 
Em 2010, o Brasil elegeu a primeira mulher presidente do país, ineditismo que não foi suficiente para alterar o quadro da representação das mulheres em cargos eletivos federais, uma vez que a legislatura da primeira mulher na presidência contou com, apenas, $9,6 \%$ de deputadas.

\begin{abstract}
As cotas que existem desde então não alteraram nada deste quadro partidário; a taxa de participação de candidatas e eleitas permanece estagnada. Comparem as bancadas eleitas em 2006 e 2010: tem-se um mesmo número de mulheres eleitas, nem parece que houve uma mudança na legislação eleitoral que determinou em 2009 uma mudança na legislação eleitoral para estimular as candidaturas femininas... Estas regras estão escritas nas leis, mas não nas vidas das mulheres (BANDEIRA; MELO, 2010, p. 30).
\end{abstract}

As eleições municipais de 2012 apresentaram leve incremento, pois as mulheres se elegeram para 13,3\% das cadeiras das câmaras municipais e 11,8\% das prefeituras (TSE, 2012, on line). Ainda que se considere este aumento um avanço, a presença feminina em cargos públicos eletivos é ínfima, especialmente, se analisada a partir do dado de que as mulheres correspondem a 51,5\% da população brasileira (PNAD; IBGE, 2011, on line). Ademais, em junho de 2013, as mulheres brasileiras correspondiam a $52 \%$ do total de eleitores e a $58 \%$ dos eleitores com curso superior completo.

A Secretaria de políticas para as Mulheres do Governo Federal, em sua avaliação sobre a eleição de 2012, já sob a égide da minirreforma eleitoral, afirmou:

Não podemos perder de vista uma questão central: a efetiva igualdade de gênero na
política não será resolvida por mudanças institucionais pontuais, ainda que essas pos-
sam contribuir com o processo. Para que a igualdade se coloque na ordem do dia será
necessário ir às raízes do problema, buscando refletir as razões que afastam as mu-
lheres da política e a articulação dessa ausência com outras manifestações da desi-
gualdade de gênero, assim como de raça, orientação sexual, etc. (BRASIL, 2012, on
line, p. 64).

Na legislatura de 2010-2014, 46 mulheres ocuparam cadeiras na Câmara dos Deputados. Nas eleições de 2012 para prefeituras e câmaras de vereadores, as mulheres se elegeram para 8.287 vagas de vereadoras, representando $13,9 \%$ do total das cadeiras de vereança do país, e para 657 prefeituras, correspondendo a 11,84\% das cidades brasileiras (SPM, on line).

O Brasil, que em 2013 estava na já desconfortável 120ª posição (IPU, 2013, on line) dentre os mais de 190 países analisados pela ONU Mulheres e União Interparlamentar - UIP, no ranking sobre participação política das mulheres no parlamento, ocupa atualmente a $154^{\mathrm{a}}$ posição, com 55 das 513 cadeiras da Câmara Federal e 12 dos 81 assentos do Senado ocupados por mulheres (ONU Brasil, 2017, on line). A situação piora quando o cenário é o Poder Executivo, "com apenas uma ministra, o Brasil ficou na $167^{\mathrm{a}}$ posição no ranking mundial de participação de mulheres no Executivo, que analisou 174 países” (ONU Brasil, 2017, on line).

Resta inconteste que a presença significativa de mulheres em cargos políticos eletivos permanece um desafio. Confirma-se que as cotas não são suficientes e, neste sentido, importante apresentar algumas ponderações que objetivam compreender o pouco avanço, apesar da existência de uma política de cotas.

A existência da cláusula de escape e a não previsão de punição pelo não cumprimento da cota contribuíram para que não houvesse uma forte resistência à política de cotas, especialmente, por parte dos homens, uma vez que suas candidaturas não foram afetadas pela mudança. Demonstra-se, destarte, que não houve mudanças estruturais, o que confere aos avanços obtidos um caráter mais simbólico do que real, ao menos, a curto prazo.

Ainda no que tange à reflexão sobre a (in)eficiência da cota eleitoral, diversos autores apontam o sistema político eleitoral do Brasil como um fator determinante para o não êxito da 
ação afirmativa. No Brasil, o sistema eleitoral é de lista aberta, cada partido apresenta seus candidatos e candidatas em uma lista não ordenada e os eleitores escolhem em quem votar.

Na democracia brasileira, o poder de escolha está com o eleitor e os candidatos competem entre si (seja com os candidatos dos outros partidos, seja com os candidatos do seu próprio partido) por uma vaga. Outras democracias optam pelo sistema de listas fechadas, em que o partido político organiza uma lista pré-ordenada que determina a ordem de eleição dos candidatos, a partir do número de votos que o partido receber. O eleitor vota no partido e não no candidato em si. O poder de decidir quem estará no início da lista e com maiores chances de eleição está nas mãos dos dirigentes partidários e não do eleitor.

Na análise de Clara Araújo (2001, p. 19), a lista aberta traz mais dificuldade ao processo de maior equilíbrio representativo:

\begin{abstract}
As cotas tendem a apresentar maior eficácia nos sistemas de listas fechadas ou semifechadas e menor nos sistemas de listas abertas. A formação de uma lista de nomes para concorrer em sistemas eleitorais como o do Brasil, em que o voto pode ser exclusivamente no candidato e a competição é muito individualizada, tende a ser um procedimento formal e legal. Não se vota em lista, mas sim no candidato. É ele que o eleitor fica conhecendo na propaganda eleitoral, muitas vezes feita de maneira desvinculada do partido. Desse modo, compor uma lista de nomes partidários não diz nada sobre prioridades ou estar efetivamente no cenário da disputa.
\end{abstract}

Entretanto, referido posicionamento é controverso. Autores como Rule e Shugart (1995, on line) defendem que a lista aberta não é obrigatoriamente um empecilho para composição de um parlamento mais equânime. Apontam, em uma pesquisa com 28 países, realizada entre 1970 e 1991, que nos Estados onde as listas são fechadas ou possuem voto distrital as mulheres têm menos condições de conseguir se eleger: "Women would appear to have less opportunity for parliamentary election where voter's choice is limited, where they must choose only a fixed party slate of candidates, and where single members districts are used, as in the United States" "12 ([s/ d], on line).

Importante ressaltar, entretanto, que os autores brasileiros, na sua maioria, entendem a lista aberta como uma dificuldade para as cotas eleitorais. Luiz Felipe Miguel (2000, p. 99) reforça as ideias de Clara Araújo (2001), e compara o sucesso das cotas eleitorais nos países escandinavos ao fraco desempenho no Brasil:

\begin{abstract}
A diferença pode ser, em parte, creditada ao sistema eleitoral. Um sistema de listas fechadas, como adotado na Suécia e na Noruega, faz com que a alteração promovida pelos partidos na seleção dos candidatos seja transferida quase automaticamente para os eleitos. No caso brasileiro, em que o eleitor vota antes no candidato do que no partido, a possibilidade de grandes disparidades entre a composição das listas de candidatos e do parlamento é bem maior.
\end{abstract}

Outro fator apontado como uma dificuldade institucional ao sucesso da lei de cotas seria a falta de cláusula de barreiras no sistema eleitoral brasileiro. Existe um universo de pequenos partidos políticos que não necessitam de um resultado eleitoral mínimo para continuar existindo.

Houve uma tentativa de se impor uma cláusula de barreira no Brasil ${ }^{13}$, contudo, o Superior Tribunal Federal - STF compreendeu que referida cláusula cercearia o direito à livre criação dos partidos políticos, em uma afronta ao artigo 17, caput, da Constituição Federal de 1988 - CF/88:

\footnotetext{
12 "As mulheres parecem ter menos oportunidade para a eleição parlamentar em que a escolha do eleitor é limitada, quando deve escolher apenas uma chapa de candidatos do partido fixo, e quando são utilizados distritos únicos, como nos Estados Unidos" (tradução livre).

13 Por meio da Lei 9.096/1995, quando se aprovou que a partir de 2006 os partidos que não alcançassem 5\% do eleitorado nacional perderiam direitos nas casas legislativas e recursos do fundo partidário, bem como teriam o tempo de rádio e televisão diminuídos.
} 
“É livre a criação, fusão, incorporação e extinção de partidos políticos, resguardados a soberania nacional, o regime democrático, o pluripartidarismo, os direitos fundamentais da pessoa humana" (BRASIL, 1988, on line).

O STF decidiu pela inconstitucionalidade da proposição, sob o fundamento de que limitar a criação e a ampla participação de partidos políticos no processo eleitoral brasileiro seria, também, incompatível com o disposto no artigo $1^{\circ}$ da Constituição Federal de 1988 - CF/88.

Desta forma, o sistema partidário brasileiro continua a ser um dos mais fragmentados do mundo, tendo um grande número de pequenos partidos.

Atualmente, tramita no Congresso Nacional uma série de projetos de lei que almejam ampliar a participação feminina na política e, mais especificamente, nos cargos eletivos ${ }^{14}$. Os debates acerca da reforma política têm incluído opiniões diversas sobre as formas possíveis de impulsionar a igualdade de representação, mas ainda não se chegou a um consenso sobre qual método seria mais eficiente ou mesmo se seria por meio de ação afirmativa de cotas que se transformaria essa realidade.

Destarte, chega-se a 2017 com a certeza de que a participação feminina na política brasileira é inexpressiva e que a existência de cotas eleitorais não é suficiente. É imprescindível que haja uma sensibilização e preparação das mulheres para a relevância de ocuparem cargos públicos eletivos.

\begin{abstract}
Estudo comparativo com outros países revela que a aplicação da lei não é suficiente para que haja incremento na quantidade de cadeiras ocupadas por mulheres, sendo necessário capacitar e criar programas de apoio, realizando campanhas de incentivo, a fim de despertar as condições para que as mulheres participem dos processos decisórios da nação. As mulheres ocupam hoje baixos percentuais de vagas nos cargos eletivos no Brasil. São $10 \%$ dos deputados federais e $14 \%$ dos senadores, embora
\end{abstract}

141 - PL-23552/2000 (autora: Rita Camata): Destina metade das vagas para cada sexo, nas eleições para a Câmara dos Deputados, Assembleias Legislativas e Câmaras Municipais; 2 - PL-4649/2001 (autor: Paulo Baltazar): Aumenta para cinquenta por cento o número de vagas para cada partido ou coligação deverá reservar para candidaturas de cada sexo (homem e mulher); 3 - PL-6216/2002 (autora: Luiza Erundina): Destina 30\% (trinta por cento) dos recursos do fundo partidário à criação e manutenção de programas de promoção da participação política das mulheres, e prevê tempo na propaganda partidária gratuita para a mesma finalidade; 4 - PL-286/2003 (autora: Laura Carneiro): Destina pelo menos $30 \%$ (trinta por cento) dos recursos dos Fundos Partidários à formação e capacitação política feminina; 5 - PL-719/ 2003 (autora: Mariângela Duarte): Destina, no mínimo, 30\% (trinta por cento) dos recursos oriundos do Fundo Partidário para a criação de instituto ou fundação de pesquisa e de doutrinação e educação política, e no mínimo $30 \%$ (trinta por cento) para a capacitação política da mulher; 6 - PL-4804/2005 (autora: Vanessa Grazziotin): Obriga cada partido ou coligação a preencher a cota mínima de candidatura registrada de cada sexo; acarreta a nulidade do pedido de registro das candidaturas em caso de descumprimento do limite fixado; 7 - PL-607/2007 (autor: Jô Moraes): Altera a Lei $\mathrm{n}^{\circ}$ 9.504, de 30 de setembro de 1997, que estabelece normas para as eleições, instituindo multa em caso de descumprimento da cota de candidaturas de cada sexo; 8 - PL-608/2007(autor: Jô Moraes): Altera a Lei nº 9.504, de 30 de setembro de 1997, que estabelece normas para as eleições, instituindo a lista preordenada de candidatos e a cota de candidaturas de cada sexo; 9 - PL-1210/2007 (autor: Regis de Oliveira): Dispõe sobre as pesquisas eleitorais, o voto de legenda em listas partidárias preordenadas, a instituição de federações partidárias, o funcionamento parlamentar, a propaganda eleitoral, o financiamento de campanha e as coligações partidárias, alterando a Lei $\mathrm{n}^{\circ} 4.737$, de 15 de julho de 1965 (Código Eleitoral), a Lei n ${ }^{\circ}$ 9.096, de 19 de setembro de 1995 (Lei dos Partidos Políticos) e a Lei ${ }^{\circ}$ 9.504, de 30 de setembro de 1997 (Lei das Eleições); 10 - PL-4636/2009 (autor: Poder Executivo): Altera a Lei ${ }^{\circ}$ 4.737, de 15 de julho de 1965, e a Lei $\mathrm{n}^{\circ}$ 9.504, de 30 de setembro de 1997, para dispor sobre o voto em listas partidárias pré-ordenadas. Na proposta apresentada os partidos ficariam obrigados a garantir ao menos na primeira metade das suas listas, a existência de ambos os gêneros a cada três candidatos. (além do Projeto de Lei n ${ }^{\circ} 4634 / 2009$, especifico para o financiamento público de campanha); 11 - PL-6316/2013 (autor: Luísa Erundina e outros): Dispõe sobre o financiamento das campanhas eleitorais e o sistema das eleições proporcionais alterando a lei $\mathrm{n}^{\circ}$ 4.737/65 (código eleitoral), a Lei $n^{\circ}$ 9096/95 (Lei dos Partidos Políticos), Lei n 9504/97 (Lei das eleições) e a Lei ${ }^{\circ}$ 9709/98 que discorre sobre a forma de subscrição de eleitores e iniciativa popular. Disponível para consulta em: www.camara.gov.br. 
sejam metade da população e da força de trabalho na economia. O percentual é idêntico nas Assembleias Estaduais e menor ainda nas Câmaras de Vereadores e no Poder Executivo (TSE, 2016, on line).

Há diversos projetos que propõem alterações à legislação eleitoral brasileira, dentre os quais onze contemplam algum tipo de política pública para ampliar a presença das mulheres no cenário político nacional ${ }^{15}$. Os projetos, na sua maioria de autoria de deputadas, pretendem dar mais efetividade à política de cotas já instituída, tentando preencher as lacunas que a estrutura atual tem, como falta de punição aos partidos não cumpridores das cotas e o não cumprimento dos percentuais relativos ao recurso do fundo partidário e ao tempo de rádio e televisão para as campanhas das mulheres.

\section{PARA AlÉM da POLÍTiCA de COTAS: Algumas REFLEXõeS}

Uma reflexão que se impõe sobre o tema é se a presença da mulher no parlamento é suficiente para fazer com que o sistema de representação política se torne mais democrático e se configure em um espaço de efetiva contribuição igualitária de homens e mulheres.

Esse ponto de inflexão é relevante, pois se desdobra na ponderação sobre a necessidade de as mulheres eleitas (vereadoras, deputadas, governadoras etc.) protagonizarem uma atuação comprometida com temas historicamente alinhados à luta pelos direitos das mulheres, como igualdade salarial e enfrentamento à violência doméstica e familiar.

Por um lado, o aumento do número de mulheres em cargos eletivos é, por si só, uma conquista, na medida em que a política, em especial os cargos eletivos, é um espaço ocupado predominantemente por homens ${ }^{16}$.

O IBOPE e o Instituto Patrícia Galvão, com o apoio da ONU MULHERES, são responsáveis por desenvolver a pesquisa Mais Mulheres na Política, por meio da qual se constatou que $71 \%$ dos entrevistados consideram a reforma política importante ou muito importante para garantir 50\% de homens e 50\% de mulheres nas listas de candidaturas dos partidos; 8 em cada 10 entrevistados consideram que deveria ser obrigatória a participação das mulheres em metade das cadeiras nas casas legislativas já que as mesmas correspondem a metade da população; $78 \%$ concordam que os partidos políticos deveriam apresentar suas listas de candidatos com 50\% de cada gênero e $73 \%$ defendem punição aos partidos que não cumprirem essa determinação dos 50\%: "Os resultados da Pesquisa Ibope/Instituto Patrícia Galvão indicam, de forma contundente, a demanda da sociedade brasileira pelo fortalecimento e ampliação da participação das mulheres nos espaços de poder e decisão". (IBOPE; INSTITUITO PATRÍCIA GALVÃO, on line).

As mulheres representam mais de $50 \%$ do eleitorado brasileiro, conforme indicado anteriormente, não sendo razoável que se mantenha índices tão baixos de representação. Em uma democracia espera-se que na definição das questões gerais da política pública a população esteja proporcionalmente representada. Romper com essa reprodução sistemática pode ser apontada

${ }^{15} \mathrm{Na}$ contramão desses projetos, indica-se o projeto de iniciativa popular capitaneado pela Ordem dos Advogados do Brasil-OAB, referente à reforma política, não faz uma só referência a políticas específicas sobre igualdade de gênero. A proposta defende eleições mais transparentes, com maior controle social, menor número de candidatos, mas não faz menção a uma maior igualdade entre homens e mulheres (CARTILHA ELEIÇÕES LIMPAS, on line).

16 Neste sentido, relevante indicar o compromisso do Comitê da CEDAW em acompanhar os desdobramentos dos esforços dos Estados signatários da Convenção para a equidade na participação da vida política e pública. Para uma leitura sobre o tema vide (PRÁ, 2014). 
como um ganho. A política de presença é um primeiro passo para a consolidação da igualdade de participação.

É preciso compreender que em uma democracia representativa, como no caso do Brasil, o parlamento deve ser uma expressão da diversidade da sociedade a qual ele representa " [...] ele não precisa refletir exatamente as características de seu povo, mas, para que seja minimamente representativo, deve guardar uma proporção de identidade entre representantes e representados, com características sociais comuns entre ambos" (PINHEIRO, 2006, p. 106). Destarte, a presença feminina em contingente, minimamente, representativo, deve ser buscada.

Em um cenário ideal, as políticas de cotas seriam tema ultrapassado, pois a presença feminina em assentos eletivos seria uma realidade consolidada. Entretanto, não é o panorama da política brasileira.

Por outro, deve-se reconhecer que a discriminação de gênero é realidade multifacetada, a qual demanda ações diversas, reconhecendo-se a limitação dos benefícios oriundos deste equilíbrio numérico. Nas palavras de Miguel (2000, p. 34): “As cotas não ampliam a representação das mulheres, apenas o número de mulheres atuando como representantes. Quer dizer, elas não garantem, por si só, que o sistema político se torne mais receptivo às demandas das mulheres".

A maior presença das mulheres como representantes é a superação de uma desigualdade, mas não necessariamente avança nas conquistas sobre a agenda feminista. Nas palavras de Miguel (2000, p. 34):

Assim, creio que existem dois processos paralelos, que se relacionam entre si, mas não se esgotam um no outro. Um é a ampliação da presença das mulheres nos espaços da política, que inclui, como mecanismo importante, as cotas. Outro é a ampliação do peso da agenda feminista no debate público.

A relevância da participação das mulheres nos espaços de poder tem se justificado por diversos argumentos, dentre os quais se destaca 1) a política de desvelo; e a 2) dicotomização de interesses entre assuntos de homem $\mathrm{x}$ assuntos de mulher.

$\mathrm{O}$ primeiro se refere à alegada diferença comportamental entre homens e mulheres, em que a presença da mulher na política seria o caminho para uma política mais sensível, mais afável, mais generosa, pois a mulher traria para política um olhar de defesa de valores mais humanos, em contraponto com a postura agressiva dos homens, que entendem a política apenas como um jogo de poder (PINHEIRO, 2006).

Essa política de desvelo reflete a "Ideia de que as mulheres trariam um aporte diferenciado à esfera política, por estarem acostumadas a cuidar dos outros e a velar pela família" (MIGUEL, 2000, on line) encontra diversas críticas pois reafirma a naturalização das diferenças e nem sempre condiz com a realidade.

\begin{abstract}
Tal visão, no entanto, tem sido alvo de inúmeras críticas. Primeiro, por ratificar papéis de gênero, deslizando sempre para a naturalização das diferenças. Segundo, porque a experiência de mulheres no poder tem demonstrado que a relação entre gênero e "política de desvelo" não é inequívoca, o que indica que homens e mulheres podem exercer o poder da mesma maneira (PINHEIRO, 2006, p. 53).
\end{abstract}

Outra crítica contundente à política de desvelo diz respeito à caracterização da atuação das mulheres como uma ação em prol dos outros, uma atuação desinteressada, diferente da atuação masculina que seria, por princípio, uma política de interesse. Esse entendimento, novamente, coloca a mulher no lugar de um sujeito que não tem interesse próprio, que sempre coloca a vontade/necessidade dos outros acima dos seus desejos, objetivos, um sujeito submetido. 
O segundo aspecto refere-se às diferenças de interesses entre homens e mulheres, as quais interfeririam diretamente na pauta de atuação de cada um. As mulheres precisariam estar representadas, pois as mesmas têm temáticas próprias que só elas poderiam defender. Seria papel da mulher lutar por creches, por políticas de saúde da mulher, por melhores maternidades, por leis trabalhistas de assistência às gestantes, contra a discriminação sexual, enfim, por temas que os homens não teriam interesse por não dialogarem com problemas que os afligem cotidianamente.

Questiona-se o entendimento de que apenas o fato de ser mulher não é suficiente para definir sua atuação política. Outras características como etnia, classe social, orientação sexual, origem familiar, ideologia partidária influenciam suas decisões, e o fato de ser mulher pode não ser suficiente para comprometer alguém com as questões femininas e mesmo dentre as questões ditas femininas as histórias de cada mulher moldará sua forma de atuação. Ademais, perceba-se que os ditos temas femininos são, na realidade, assuntos de interesse de toda a sociedade.

Reconhece-se que há diferenças inerentes às vivências que se dão a partir dos papeis sócio culturalmente estabelecidos para homens e mulheres: "a inclusão de mulheres na esfera política é a possibilidade de realmente se alcançar o pluralismo de perspectivas que caracteriza sociedades tão fragmentadas como as contemporâneas" (PINHEIRO, 2006, p. 56).

Percentual significativo da população ainda acredita e convive com papeis estanques e predeterminados para homens e mulheres. Neste sentido, ainda que se defenda que as atividades e funções da vida pública e privada são intercambiáveis, entende-se que a ordem social vigente ainda impõe o parâmetro dicotômico, que balizou a formação dos homens e das mulheres atualmente aptos a ocupar cargos públicos. Desta forma, ao menos a curto prazo, garantir a contribuição das mulheres na vida pública significa contemplar paradigma diferente do defendido pelos homens.

Todavia, habilidades são aprimoradas e novos saberes apreendidos, diante disto, é necessário que as mulheres experienciem a vida pública, as responsabilidades, desafios e competências necessárias aos cargos públicos. Legislar se aprende legislando, e para as mulheres conseguirem atuar nos espaços de poder de forma eficiente e adequada é imprescindível que ocupem esse espaço.

Diante disto, defende-se a relevância de uma participação, senão proporcional, ao menos significativa de mulheres na política brasileira como uma forma de fortalecer o pacto democrático nacional, que pugna por uma sociedade justa, igualitária e livre de quaisquer espécies de discriminação.

\section{AS MUlHeres NO CONGRESSO NACIONAL BRASILEIRO: CONTRIBUIÇÕES SOBRE PERFIL E ATUAÇÃO}

As poucas parlamentares eleitas no Brasil têm um perfil que merece atenção, pois seu conhecimento possibilita uma melhor compreensão sobre as motivações que alçam referidas mulheres à vida pública.

Neste sentido, as pesquisas desenvolvidas por Pinheiro (2006) e Miguel (2003) arrimarão as reflexões a seguir apresentadas, pois parte da premissa de que as pessoas ao ingressarem no campo político trazem algum tipo de capital político, isto é, alguma força social elou simbólica capaz de garantir votos e legitimidade (PINHEIRO, 2006), o que se aplica, indistintamente, aos homens e às mulheres. 


\begin{abstract}
O capital político é, em grande medida, uma espécie de capital simbólico; o reconhecimento da legitimidade daquele indivíduo para agir na política. Ele baseia-se em porções de capital cultural (treinamento cognitivo para a ação política), capital social (rede de relações estabelecidas) e capital econômico (que dispõe do ócio necessário à política). Como toda forma de capital, o capital político está desigualmente distribuído na sociedade. Na base da pirâmide temos os simples eleitores que podem apenas optar por uma entre as alternativas propostas, sem praticamente nenhuma voz ativa na vida política; no topo, os líderes que são os autores das alternativas em jogo e que são reconhecidos como representantes dos diversos segmentos sociais. (MIGUEL, 2003, p. 121).
\end{abstract}

Neste sentido, ambos os autores partem das premissas estabelecidas por Bourdieu (994) sobre dominação e poder simbólico ${ }^{17}$ e recriam categorias de capital político mais próximos da realidade brasileira. Desta forma, Miguel (2003) apresenta o capital delegado e o capital convertido como categorias do capital político, em razão da fragilidade das estruturas partidárias e superficialidade do capital político dos partidos brasileiros.

Para o autor (MIGUEL, 2003, p. 121) o capital delegado pode ser compreendido como o capital originário do próprio campo político e/ou estatal, ou seja, da prévia ocupação de cargos públicos (eletivos ou cargos de confiança) no Poder Executivo, da notoriedade por mandatos eletivos anteriores, e da militância partidária; o capital convertido origina-se da popularidade obtida em outros campos (médicos, cantores, esportistas de renome), a qual é deslocada para a política, bem como a transferência do capital econômico, por meio de campanhas eleitorais dispendiosas.

As reflexões de Pinheiro (2006), partindo da divisão proposta por Miguel (2003), apresenta uma tipologia, com o intuito de melhor compreender a realidade brasileira, em especial, a relevância de cada uma na eleição de parlamentares mulheres, no interregno de 1987 a 2002.

Aponta 1) capital político delegado (subdividido em 1.1 capital político delegado da família; 1.2 capital político delegado do campo político; e 1.3 capital político delegado de movimentos sociais); e 2) capital político convertido.

O capital político delegado, subdividido nas 3 categorias acima mencionadas, alberga a ideia de que há uma expertise sobre as particularidades do campo político que desenvolvida por meio de 1) envolvimento da família com o campo político; 2) ocupação de cargos políticos não eletivos; e 3) militância em movimentos sociais,

O capital político delegado da família é oriundo das relações familiares, seja por nascimento ou casamento; no caso das mulheres seja por ser filha, mãe ou esposa. Talvez seja o capital político mais tradicional e nem sempre visto com bons olhos pelas feministas da atualidade, por entenderem que a eleição não foi, de fato, uma conquista das mulheres, mas sim um espaço dado à mulher em nome de um homem: "[está] mais relacionado às instituições - partidos ou famílias - à ocupação de cargos públicos e políticos e à própria militância partidária" (PINHEIRO, 2006, p. 89-90).

O capital político delegado da ocupação de cargos políticos não eletivos é o de capital político oriundo de uma notoriedade técnica. Há o reconhecimento público e notório da competência técnica, que viabiliza a transição para a política. Normalmente quem tem esse capital político tem uma bandeira única e consolidada, resultado do seu saber técnico e atuação profissional destacados.

17 Bourdieu (1994) não desenvolve uma catalogação estática das "espécies” de capital político, mas, de acordo com Miguel (2003) pode-se apontar, a partir das contribuições do sociólogo francês 3 subdivisões para o capital político: capital delegado, capital convertido e capital heroico. 
O capital político delegado pela participação em movimentos sociais é conquistado pelas mulheres oriundas dos sindicatos, dos movimentos sociais urbanos e rurais, do movimento feminista, das lideranças que se forjaram na luta popular, principalmente, ocorrida após a redemocratização do Brasil.

O capital político convertido, por sua vez, se refere à pessoa que em sua atividade profissional de origem alcançou peculiar destaque, agregou valor à sua imagem e atuação. Diante disto, sua influência transcende este espectro inicial (sua área de atuação específica) e a alça à vida política: "originado de outros campos - como o esportista, o artístico ou o intelectual - e que se converte, em maior ou menor grau, em capital próprio da política" (PINHEIRO, 2006, p. 90). E ainda: "mulheres que, em função de seu reconhecimento em outros campos que não o político, conseguiram uma votação expressiva” (PINHEIRO, 2006, p. 96).

A partir da análise dos dados consolidados na tabela abaixo, percebe-se que mais de $40 \%$ das deputadas eleitas no período pesquisado (de 1987 a 2002) tinham o capital político familiar como seu principal esteio e $30 \%$ as deputadas oriundas dos movimentos sociais, com perfis bem diferentes. Como explica Pinheiro (2006, p 96): “os perfis políticos e sociais das deputadas não nos permitem, portanto, falar em "mulher" no Parlamento. De fato, as mulheres são múltiplas, com identidades diversas e trajetórias distintas".

Tabela 1 - Distribuição das deputadas, por tipo de capital político - Brasil, 1987 a 2002

\begin{tabular}{|c|c|c|}
\hline TIPO DE CAPITAL POLÍTICO & $\mathbf{N}^{\circ}$ ABSOLUTO & $\mathbf{\%}$ \\
\hline Capital político delegado & 37 & 48,7 \\
\hline Delegado dos movimentos sociais & 23 & 30,3 \\
\hline Delegado da ocupação de cargos não eletivos & 14 & 18,4 \\
\hline Delegado das famílias & 31 & 40,8 \\
\hline Capital político convertido & 8 & 10,5 \\
\hline Total & $\mathbf{7 6}$ & $\mathbf{1 0 0}$ \\
\hline
\end{tabular}

Fonte: PINHEIRO (2006, p. 116).

Contudo, a forma como as mulheres ingressam nos espaços de poder não responde inteiramente por sua atuação. As bandeiras partidárias, regionais, familiares e de movimentos específicos obviamente percorrerão a atuação das parlamentares. Porém, é um traço comum focarem as suas atuações legislativas em assuntos entendidos como "de mulher", como, saúde, educação, e outros tema de cuidado. A conclusão do Relatório Anual 2009/2010 do Observatório Brasil da Igualdade de Gênero (BRASIL, 2010, p. 42) aponta que:

Importante ter em consideração, ainda, a divisão sexual que se estabelece na ocupa-
ção de postos de decisão, segundo a área a que se refiram. As mulheres acabam vol-
tando-se - ou sendo voltadas - para áreas que, de alguma forma, retomam uma
visão estereotipada das atividades femininas. Elas se tornam responsáveis por áreas
da saúde, da criança, de direitos humanos, enfim, áreas do cuidado. Áreas normal-
mente também menos valorizadas do que as majoritariamente masculinas.

No intuito de ilustrar o ponto exposto, observa-se a composição das comissões da Câmara dos Deputados 2013: enquanto a comissão de educação da câmara conta com cinco mulheres na titularidade, a comissão de desenvolvimento econômico, indústria e comércio conta apenas com uma.

Outro exemplo sobre a divisão sexual da atuação política, sem levar em conta diferenças ideológicas, partidárias e/ou regionais, é o quantitativo de proposições apresentadas por mulheres nas comissões permanentes. 
No quadro abaixo verifica-se que o maior número de propostas sobre mulheres acontecem em comissões como seguridade social e família e que, em algumas comissões estereotipicamente masculinas, como comissão de segurança pública e combate ao crime organizado, não há sequer uma proposição que dialogue com as necessidades femininas (em uma estranha desconsideração, v. $g$., sobre o aumento do número de mulheres encarceradas no Brasil e no mundo, tema adstrito às discussões sobre segurança pública, crime organizado e sistema de justiça).

Tabela 2 - Quantitativo de proposições sobre a mulher por comissão permanente

\begin{tabular}{|c|c|c|c|}
\hline Comissão & $\begin{array}{l}\text { Proposições } \\
\text { na Comissão } \\
\text { (A) }\end{array}$ & $\begin{array}{l}\text { Proposições } \\
\text { sobre a mulher } \\
\text { (B) }\end{array}$ & $\begin{array}{l}\text { Percentual } \\
(\mathrm{B}+\mathrm{A})\end{array}$ \\
\hline $\begin{array}{c}\text { Comissão de Agricultura, Pecuária, } \\
\text { Abastecimento e Desenvolvimento Rural } \\
\text { (CAPADR) }\end{array}$ & 125 & 0 & $0,0 \%$ \\
\hline $\begin{array}{l}\text { Comissão de Ciência e Tecnologia, } \\
\text { Comunicação e Informática (CCTCI) }\end{array}$ & 482 & 1 & $0,21 \%$ \\
\hline $\begin{array}{c}\text { Comissão de Constituição e Justiça e } \\
\text { Cidadania (CCJC) } \\
\end{array}$ & 3.092 & 37 & $1,2 \%$ \\
\hline Comissão de Cultura (CCULT) & 191 & 0 & $0,0 \%$ \\
\hline Comissão de Defesa do Consumidor (CDC) & 344 & 0 & $0,0 \%$ \\
\hline $\begin{array}{l}\text { Comissão de Desenvolvimento Econômico, } \\
\text { Indústria e Comércio (CDEIC) }\end{array}$ & 155 & 1 & $0,65 \%$ \\
\hline Comissão de Desenvolvimento Urbano & 55 & 0 & $0,0 \%$ \\
\hline $\begin{array}{l}\text { Comissão de Direitos Humanos e Minorias } \\
\text { (CDHM) }\end{array}$ & 93 & 1 & $1,08 \%$ \\
\hline Comissão de Educação (CE) & 312 & 1 & $0,32 \%$ \\
\hline Comissão de Finanças e Tributação (CFT) & 1.005 & 3 & $0,3 \%$ \\
\hline $\begin{array}{c}\text { Comissão de Fiscalização Financeira e } \\
\text { Controle (CFFC) }\end{array}$ & 241 & 0 & $0,0 \%$ \\
\hline $\begin{array}{c}\text { Comissão de Integração Nacional, } \\
\text { Desenvolvimento Regional e da Amazônia } \\
\text { (CINDRA) }\end{array}$ & 123 & 0 & $0,0 \%$ \\
\hline Comissão de Legislação Participativa (CLP) & 109 & 0 & $0,0 \%$ \\
\hline $\begin{array}{c}\text { Comissão de Meio Ambiente e } \\
\text { Desenvolvimento Sustentável (CMADS) } \\
\end{array}$ & 327 & 0 & $0,0 \%$ \\
\hline Comissão de Minas e Energia (CME) & 150 & 0 & $0,0 \%$ \\
\hline $\begin{array}{c}\text { Comissão de Relações Exteriores e de } \\
\text { Defesa Nacional (CREDN) }\end{array}$ & 134 & 0 & $0,0 \%$ \\
\hline $\begin{array}{c}\text { Comissão de Segurança Pública e Combate } \\
\text { ao Crime Organizado (CSPCCO) }\end{array}$ & 211 & 0 & $0,0 \%$ \\
\hline $\begin{array}{l}\text { Comissão de Seguridade Social e Família } \\
\text { (CSSF) }\end{array}$ & 818 & 20 & $2,44 \%$ \\
\hline $\begin{array}{l}\text { Comissão de Trabalho, de Administração e } \\
\text { Serviço Público (CTASP) }\end{array}$ & 629 & 7 & $1,11 \%$ \\
\hline Comissão de Turismo e Desporto (CTD) & 140 & 0 & $0,0 \%$ \\
\hline Comissão de Viação e Transporte (CVT) & 370 & 0 & $0,0 \%$ \\
\hline TOTAL & 9.106 & 71 & $\mathbf{0 , 7 8 \%}$ \\
\hline
\end{tabular}

Fonte: Procuradoria Especial da Mulher da Câmara dos Deputados (2003, on line). 
Percebe-se que determinados assuntos não dialogam com o universo feminismo, como se fosse possível dissecar a realidade entre temas que só afetam homens e assuntos que só interessam às mulheres, em uma negação da óbvia interdependência entre os múltiplos assuntos relevantes para o bem-estar humano e da coletividade.

O que se observa, todavia, é que a atuação das mulheres está mais vinculada à sua condição feminina em detrimento de sua filiação política, ideológica. Em despeito disto, Celi Pinto (2009, p. 44) defende que "a simples presença de mulheres como vitoriosas, sejam feministas ou não, em um quadro maduro de concorrência eleitoral, é muito revelador da posição ocupada pela mulher no espaço político da sociedade".

Em um Estado Democrático de Direito deve-se atuar de acordo com a vontade da maioria, mas sem desconsiderar os direitos fundamentais das minorias, os quais precisam ser garantidos igualmente. Ademais, é importante avaliar quanto a sociedade brasileira entende a igualdade de gênero como um valor necessário à democracia; quanto a participação das mulheres, além de ser aceita, e até quista, é entendida como essencial à democracia.

\section{CONSIDERAÇões FinaIS}

A mulher brasileira participa do processo eleitoral, vota, é eleita deputada, senadora, prefeita, governadora e até presidenta, porém, esse lugar ainda não lhe é confortável. A presença feminina nos espaços institucionais de poder ainda é muito aquém da sua presença na sociedade e os avanços têm sido muito discretos nessa área desde que o Estado brasileiro admitiu a necessidade de construir uma política pública para garantir mais igualdade no legislativo.

Ratifique-se que o Brasil foi um dos primeiros países a garantir os direitos políticos para todas as mulheres, todavia, atualmente, se insere no grupo de 50 Países com menor presença de mulheres no Parlamento, atrás, inclusive, da média dos Estados americanos.

A política de cotas foi estruturada para garantir maior igualdade na representação política brasileira, por meio da ampliação da presença das mulheres nos espaços legislativos. Para tanto, é irrelevante a discussão sobre se as mulheres que irão ocupar esses postos enfrentarão ou não as questões feministas ou mesmos as historicamente femininas (em especial por não existir uma pauta exclusivamente feminina). As mulheres podem e devem pautar, livremente, suas atuações a partir das suas histórias de vida, das suas opções ideológicas, das suas identidades regionais, de movimento etc.

Podemos observar que o retrato que se apresenta é de que, apesar de o Brasil já ter avançado na conscientização da importância da participação da mulher nas esferas de poder e decisão, de o legislativo ter implantado um mecanismo de ação afirmativa com o intuito de garantir a possibilidade de mulheres competirem por uma vaga nas casas legislativas e das mulheres já terem conseguido destaque em diversas áreas socialmente relevantes, como o ambiente do trabalho e da academia, os instrumentos legais ofertados no Brasil têm demonstrado resultados muito pouco promissores.

A igualdade de gênero será uma realidade quando as mulheres e os homens, em igual proporção, compartilharem paritariamente a responsabilidade sobre o debate acerca de quaisquer assuntos relevantes para a sociedade, de economia à educação, da saúde ao trabalho doméstico. 


\section{REFERÊNCIAS}

ÁLVARES, Maria Luzia Miranda. Entre eleitoras e elegíveis: as mulheres e a formação do eleitorado na democracia brasileira - quem vota? Quem se candidadata? Cadernos Pagu, n. 43, jul.dez., 2014.

ALVES, Branca Moreira. Ideologia e feminismo: a luta da mulher pelo voto no Brasil, Petrópolis: Vozes, 1980.

ALVES, José Eustáquio Diniz. Inserção social e exclusão política das mulheres brasileiras. APARTE-Inclusão Social em Debate, jul., p. 1-15, 2009.

ARAÚJO, Clara. As cotas por sexo para a competição legislativa: o caso brasileiro em comparação com experiências internacionais, Dados, v. 44, n.1, Rio de Janeiro, 2001. Disponível em: http://dx.doi.org/10.1590/S0011-52582001000100006. Acesso em: 27 jul. 2013.

ARAÚJO, Rita de Cássia Barbosa de. O voto de saias: a Constituinte de 1934 e a participação das mulheres na política. Estud. Av. [online], 2003, vol.17, n. 49, p. 133-150. ISSN 0103-4014. http://dx.doi.org/10.1590/S0103-40142003000300009. Acesso em 13.jul.2013 p. 135.

BANDEIRA, Lourdes; MELO, Hildete Pereira. Tempos e memórias: movimento feminista no Brasil. Brasília, DF: Secretaria de Políticas para as Mulheres. [Links], 2010.

BRASIL, Presidência da República. Secretaria Especial de Políticas para as Mulheres. Relatório Anual do Observatório Brasil da Igualdade de Gênero 2009/2010, Brasília: Secretaria Especial de Política para as mulheres, 2010, p. 42.

. Secretaria de Políticas para as Mulheres. Mulheres em espaço de poder e decisão. Edição Especial da Revista do Observatório Brasil de Igualdade de Gênero, $1^{\circ}$ impressão. Brasília, 2012, p. 64. Disponível em: <www.observatoriodegenero.gov.br/menu/publicacoes/revista-anual-do-observatorio-2012/at_download/file>. Acesso em: 08 set. 2013.

CALAZANS, Myllena; CORTES, Iáris. O processo de criação, aprovação e implementação da Lei Maria da Penha. Brasil. Lei Maria da Penha comentada em uma perspectiva jurídicofeminista. Rio de Janeiro: Lumen Yuris, p. 39-63, 2011.

COSTA, Ana Alice Alcântara. O movimento feminista no Brasil: dinâmicas de uma intervenção política. 2005. Disponível em: www.revistagenero.uff.br/index.php/revistagenero/article/ download/380/285. Acesso em: 16.jul.2013.

COSTA, Thiago Cortez. Cotas e Mulher na Política: avaliando o impacto de variáveis institucionais e socioeconômicas sobre a elegibilidade feminina. 2008. ABEP - Nepo - Unicamp. Disponível em: http://www.abep.nepo.unicamp.br/encontro2008/docsPDF/ABEP2008_991.pdf. Acesso em: 21 mar. 2017.

DUARTE, Constância Lima. Feminismo e literatura no Brasil. Estudos Avançados, São Paulo, v. 17, n. 49, p. 151-172, dez. 2003. Disponível em: http://www.scielo.br/scielo.php?script=sci_arttext\&pid=S0103-40142003000300010\&lng=en\&nrm=iso. Acesso em: 14 nov., 2017.

GIULANI, Paola Cappellin. Os movimentos de trabalhadoras e a sociedade brasileira. In: DEL PRIORE. Mary (org); BASSANEZI, Carla (Coord.) História das mulheres no Brasil. São Paulo: Contexto, 2001. 
IBOPE/INSTITUTO PATRÍCIA GALVÃO. Mais Mulheres na Política. Disponível em: www.spm.gov.br/publicacoes-teste/publicacoes/2013/mais_mulheres_politica.pdf. Acesso em: 10 set. 2013.

INTER-PARLAMENTARY UNION - IPU. Women in National Parliaments. 2013. IPU. Disponível em: http://www.ipu.org/wmn-e/classif.htm. Acesso em: 10 jul. 2013.

MARTINS, Eneida Valarini. A política de cotas e a representação feminina na Câmara dos Deputados. Monografia (especialização) - Centro de Formação, Treinamento e Aperfeiçoamento (Cefor), da Câmara dos Deputados: Curso de Especialização em Instituições e Processos Políticos do Legislativo, Brasília, 2007.

MARTINS, Paulo Henrique de Souza. Processo de abolição no Ceará: história, memória e ensino. Revista Historiar, v. 6, n. 11, 2014.

MARQUES, Tereza Cristina de Novaes. Bertha Lutz. Verbete em Dicionário Mulheres do Brasil, Rio de Janeiro: Jorge Zahar, 2000, p.106.

. Elas também desejam participar da vida pública: várias formas de participação política feminina entre 1850 e 1932. 2004. Revista Gênero. Disponível em: http://www.revistagenero.uff.br/index.php/revistagenero/article/viewFile/251/171. Acesso em: 22 mar. 2017.

MIGUEL, Luis Felipe. Teoria Política Feminista e Liberalismo: o caso das cotas de representação. RBCS, n. 44, Vol. 15, outubro, 2000. Disponível em: www.scielo.be/pdf/\%0D/rbcsoc/ v15n44/4149.pdf. Acesso em: 15 jan.2013.

. Capital político e carreira eleitoral: algumas variáveis na eleição para o Congresso brasileiro. Revista Sociologia Politíca, Curitiba, n. 20, p. 115-134, Jun. 2003. Disponível em: $<$ http://www.scielo.br/scielo.php?script=sci_arttext\&pid=S010444782003000100010\&lng=en\&nrm=iso>. Acesso em: 28 mar. 2017.

ONU Brasil. Brasil fica em $167^{\circ}$ lugar em ranking de participação de mulheres no Executivo, alerta ONU. 2017. ONU Brasil. Disponível em: https://nacoesunidas.org/brasil-fica-em-167olugar-em-ranking-de-participacao-de-mulheres-no-executivo-alerta-onu/. Acesso em: 23 mar. 2017.

PINHEIRO, Luana Simões. Vozes Femininas na Política: uma análise sobre mulheres parlamentares no pós-constituinte. Universidade de Brasilia - UnB. Brasília. Dissertação de Mestrado, 237 f., 2006.

PINTO, Celi Regina Jardim. Mulher e Poder. Revista do Observatório Brasil da Igualdade de Gênero. Brasília: Secretaria Especial de Políticas para as Mulheres, 2009.

PRÁ, Jussara Reis. Mulheres, direitos políticos, gênero e feminismo. Cadernos Pagu, Campinas, n. 43, p. 169-196, dez. 2014. Disponível em: <http://www.scielo.br/scielo.php?script=sci_arttext\&pid=S0104-83332014000200169\&lng=en\&nrm=iso >. Acesso em: 14 nov. 2017.

RULE, Wilma, SHUGART Matthew. The preference Vote and Election of Women: Women win more seats in Open-List. 1995. Disponível: em http://archive.fairvote.org/reports/1995/ chp7/rule.html. Acesso em: 20 jul. 2013.

SACCHET, Teresa. Capital Social, Gênero e representação política no Brasil. Opinião Pública, v. 15, n. 2, 2009. Disponível em www.scielo.br/pdf/op/v15n2/02.pdf Acesso em 02.mai.2013, p. 308. 
Participação política das mulheres: desafios para a equidade

SOIHET, Rachel. A pedagogia da conquista do espaço público pelas mulheres e a militância feminista de Bertha Lutz. Revista Brasileira de Educação, v. 500, 2000.

O feminismo tático de Bertha Lutz. Florianópolis: Editora Mulheres; Santa Cruz do Sul: EDUNISC, 2006.

TRIBUNAL SUPERIOR ELEITORAL. Voto da Mulher. TSE. Disponível em: http:// www.tse.jus.br/eleitor/glossario/termos/voto-da-mulher. Acesso em 20 mar. 2017.

. Semana da mulher: primeira prefeita eleita no Brasil foi a potiguar Alzira Soriano. TSE. 2013. Disponível em: http://www.tse.jus.br/imprensa/noticias-tse/2013/Marco/semana-da-mulher-primeira-prefeita-eleita-no-brasil-foi-a-potiguar-alzira-solano. Acesso em: 21 mar. 2017.

Recebido em: 17 maio 2017.

Aceito em: 17 nov. 2017. 